\title{
Design of Dayak Kanayatn Language Learning Mobile Applications Using Gamification
}

\author{
https://doi.org/10.3991/ijep.v10i4.12899 \\ Paulus Suryanto ${ }^{\bowtie}$, Andi W.R. Emanuel, Pranowo \\ Universitas Atma Jaya, Yogyakarta, Indonesia \\ paulussuryanto8@gmail.com
}

\begin{abstract}
Preservation of regional languages is very important in the current globalization era. The longer the erosion of regional languages will make the younger generation do not know the language inherited from their ancestors. The fewer the speakers and interest in learning will make the Regional Language endangered. The purpose of this study is to design the learning of regional languages, especially for children aged 9-10 years with the principles of pedagogy. The method of gamification uses a mobile-based application in the form of video, quiz games, and visual images. This regional language learning design is called Enggang Kanayatn Quiz (EKQ). The lesson material will be given first, then continued with a quiz. The material in the form of daily sentences and the introduction of cultural wisdom. The result is a mobile-based application that can be used by children for the learning of regional languages with the pedagogy principle. The collected points will get an attractive reward. The contribution made through this paper is to motivate children to learn regional languages so that they will maintain cultural wisdom and regional language dances, especially Dayak $\mathrm{Ka}$ nayatn.
\end{abstract}

Keywords - Dayak Kanayatn, gamification, pedagogy, language learning.

\section{$1 \quad$ Introduction}

Regional languages are a means of communication in a region, which is an ancestral heritage that must remain preserved. The 2017 language book and language map with the publisher of the Language Development and Cultivation Agency (Badan Pengembangan dan Pembinaan Bahasa) records 652 regional languages in Indonesia [1]. The less desirable the regional language, the faster the regional language will become extinct so that the younger generation will not know the heritage of their ancestors. Extra effort must be performed to preserve this heritage, one of which by utilizing information technology approaches, and one of which is gamification.

Gamification is increasingly gaining interest because it can motivate users to increase their intrinsic needs [2]. Games played on smartphones have positive reactions from children, since the majority of children enjoy innovation in the games. The presence of this gamification method will help teachers, especially in the world of education, so that smartphones are not misused, for example, only for social media or things 
that are less useful purposes. From these problems came the idea of how to take an innovative approach to encourage students to use their mobile phones effectively in class. The gamification method is more desirable because it is the application of game features, especially video elements in games so that the application of gamification in pedagogy provides many solutions for children [5]. Learning has started since before school, and it is not only in the classroom but also outside, for example, in daily activities. Visual learning has a good memory, and most of the information presented visually is preferred, for example, in the form of graphics, maps, posters, and displays [6]. Some of the examples are game learning using puzzles for kindergarten, which focused on the introduction of objects around the environment [3] and learning mathematics [4].

In this study, the gamification was designed using a mobile phone, focusing on learning regional languages with the concept of pedagogy for children from 9 to 10 years to preserve cultural wisdom and preservation of regional languages. The method of gamification used was considered capable of motivating children to learn. By collecting, points and the presence of attractive rewards will encourage children to learn more. It is to make the design of gamification has a positive impact on education so that it can motivate learning intentions [7]. The combination of four models and 21 elements in providing information needs to be justified, and in this study, three models and several elements were taken from gamification. Table 1 shows the model and elements used in the design.

Table 1. Gamification Model

\begin{tabular}{|l|l|l|}
\hline \multicolumn{1}{|c|}{ Mechanics } & \multicolumn{1}{|c|}{ Measurement } & \multicolumn{1}{c|}{ Reward } \\
\hline Storytelling & Time & Achievements \\
\hline Visual Cues & & Enjoyment \\
\hline & & Point \\
\hline
\end{tabular}

\section{$1.1 \quad$ Pedagogy}

In most learning for children also occurs through language. Besides, the learning process also usually occurs from observing the actions of others. Other people's actions become rich information for social learning [8]. Game-based pedagogy consists of educational games, learning by making games, and gamification in learning [9]. In the learning environment, many pedagogical methods can be used. The method or art of teaching can be done with sound, movement, and visuals, as in the Animated Pedagogical Agents (APAs), which have been known as facilitating learning [10].

The method of pedagogy with the game is also a way for us to understand the children's point of view about learning through play. Also, through the game method, it can provide practical and simple insight [11]. Pedagogy in the form of games can also be applied to sports lessons, for example, in the game sense, so that it can foster a creative sense in children [12]. Information Technology and computers provide a means for learning so that they will produce effective and efficient learning[13]. 


\subsection{Dayak kanayatn}

Dayak Kanayatn is one of the hundreds of Dayak sub-tribes who inhabit the island of West Kalimantan/Borneo, precisely in the areas of Landak Regency, Mempawah District, Kubu Raya Regency, and Bengkayang Regency. Pontianak, the capital city of West Kalimantan, is located between 1-degree north latitude and 0 degrees 59 seconds south latitude, while the longitudinal line intersects with 108 degrees 35 seconds to 110 degrees seconds east longitude.

Dayak Kanayatn language is the language of ahe/nana' and damea/jera. Dayak Kanayatn Language is used in almost all aspects of activities: in the market, in the fields, rice fields, at home, and the school environment (but not in the teaching and learning process). Dayak Kanayatn language, which is used in oral form, is spoken according to its pattern and style, namely: repetition of words, phrases, sentences of high frequency, mention of terms related to the universe, work, personhood, and other lives [14]. The Dayak Kanayatn language at this time is not like the language used by the older generation; there are many vocabularies adopted and "made to be Dayak". The language used in the younger generation at this time is easier to understand because it is similar to Bahasa Indonesia or Malay.

Enggang, called Helmeted Hornbills in English, are birds that were sacred by the Dayak tribe. Hornbills are now a rare bird because the species is endangered. These Hornbills are symbols of peace and unity, harmony, and loyalty. These Hornbills are also symbolized by the Dayaks, that their thick wings are described as leaders who protect the community, their loud voices are commands that are always heard by the people, their long tails are symbols of prosperity, so overall, hornbills are considered as leaders loved by the people [15].

\section{Related Literature}

There are several previous studies about daily activities, language, and culture learning for children using the method of gamification. One study is about learning the $M a$ durese Language that uses a trivia quiz [16]. The second study is about Banjar Language and Culture of South Kalimantan in the form of the Educational Game Festival in which the game is the introduction of everyday language, fruit, animals, and Banjar special food [17]. There is also the red and white game application that adds variations of puzzle games on Android, which provide information about the culture in Indonesia [24]. In Learning with Dino, learning for children includes how to understand basic letters and spelling with twenty-six content so that they can inspire and motivate to learn the basic alphabet and spelling [18]. The incorporation of mobile technology will make students learn personally, learn anywhere, and anytime, so students are more independent [19].

There are several models of gamification for education that can be applied. Kusuma et al. use the MDA framework (Mechanics, Dynamics, Aesthetics) in which this study produces an analysis that there are several representative gamification models that can be used to increase motivation in learning activities [20]. Gamification is a powerful tool for catalyzing caution, focus, and investment. Students will be captivated by ideas 
and curiosity to learn more deeply [21]. How the effects of gamification, two methods were used, namely traditional sampling and gamification. Significant results using the gamification strategy showed the highest achievement [22]. Mobile applications provide a solution for how students can easily learn human anatomy using augmented reality technology [23]. The technology today is increasingly used to motivate and support people towards various behaviors that benefit individually and collectively, and the most popular development today is gamification [25]. Moreover, technology is expected to develop music pedagogy in a better direction, such as using technology such as MIDI, digital audio, and so on [26].

The Enggang Kanayatn Quiz is different from previous research. This study used the gamification method based on pedagogical principles. The method of gamification was used because it was considered capable of motivating children to learn. The merging of the gamification model used distinguishes the Enggang Kanayatn Quiz from the previous research. Achieving promising points and rewards will motivate children to learn.

\section{$3 \quad$ Proposed Method}

This research focused on the design of mobile applications for Dayak Kanayatn Languages learning for children aged 9-10 years using gamification and pedagogical principles. The method of gamification was considered to be able to motivate children to learn with attractive game design and by the elements of gamification. In this game, the role of parents was very helpful in assisting children in playing the game [27]. In applying principles of pedagogy, the learning game is in the form of a quiz in which there will be a delivery of material first and continued with the questions. The questions are in the form of questions in the form of pictures, the arrangement of words, and sentence structure. Every question with the correct answer will get the point. If the question is considered difficult, then there is a help facility that will provide an answer grid. Figure 1 is the flow diagram of the research.

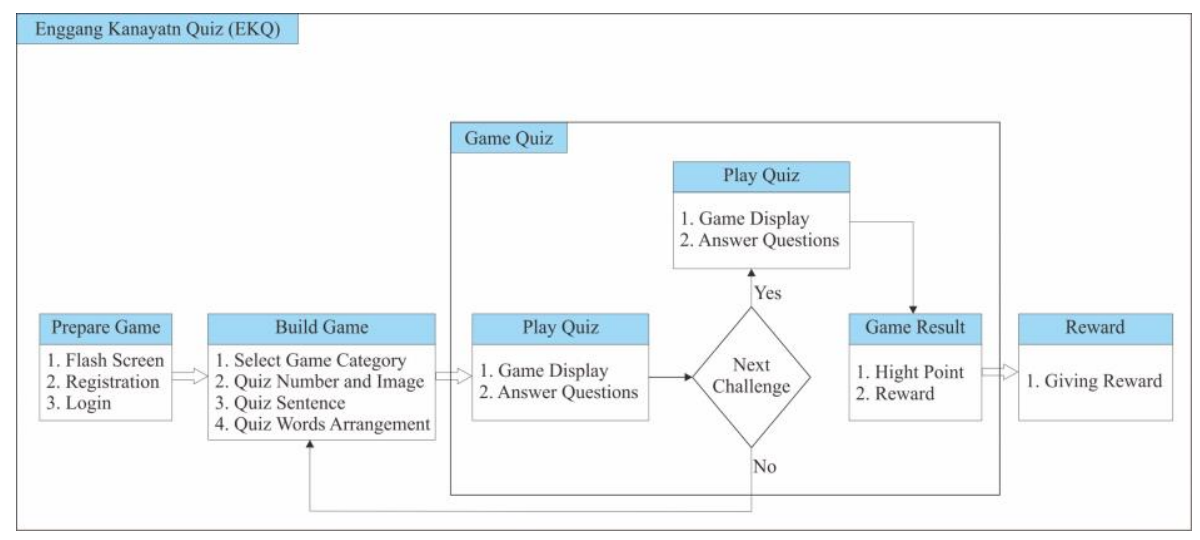

Fig. 1. Research Flow Diagram 
This stage consists of 2 parts: literature study and needs analysis. The literature study was done by reading from the internet, journals, and theses. A needs analysis was by discussing with experts in the field of education, namely regional language teachers who educate children aged 9-10 years. From the results of discussions with the experts, the form of the game with the element of gamification was following the principles of pedagogy as a basis for designing gamification on mobile.

\section{$4 \quad$ Result and Discussion}

In the result and discussion, there are discussions about the application, namely interface de-sign, interface quiz, and reward.

\subsection{Interface design mobile learning gamification}

From the results of the research and testing of the prototype, the test was carried out by the regional language teacher for children aged 9-10 years. From the test results, the prototype of the design of mobile applications for learning Dayak Kanayatn languages using gamification can be seen in the image below:

- Figure 2 shows the login display. The participant may register if they do not have an account.

- Figure 3 shows the registration display. This registration is very simple since this Regional Language learning mobile application is designed for children aged 9-10 years.

- Figure 4 shows the category display. In this category, the user can choose the game in the form of a quiz, multiple-choice, and drag and drop. The time given is 20 minutes with a green sign if the game has completed, and red sign if it is not yet played. 


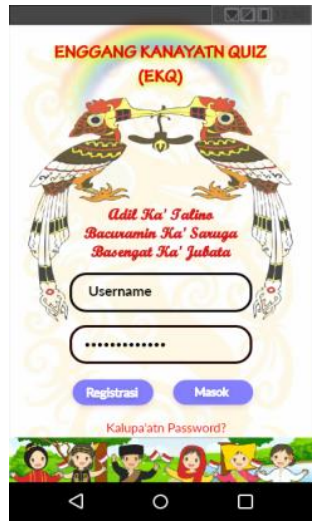

Fig. 2. Login Display

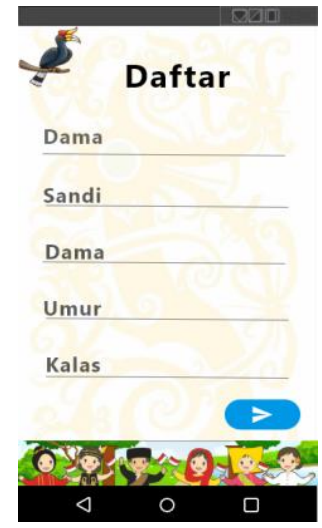

Fig. 3. Registration Display

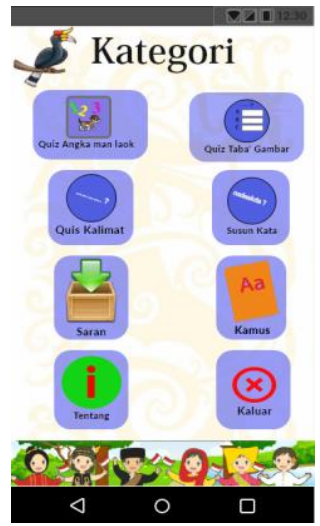

Fig. 4. Category Display

\subsection{Numbers and image interface quiz}

In this quiz, the learning uses drag and drop. In fig 5, the material about numbers is explained first by an avatar from numbers 1 to 10 , then continued with the quiz shown in fig 6. Example question in fig 6 is number one $\left(A s a^{\prime}\right)$.

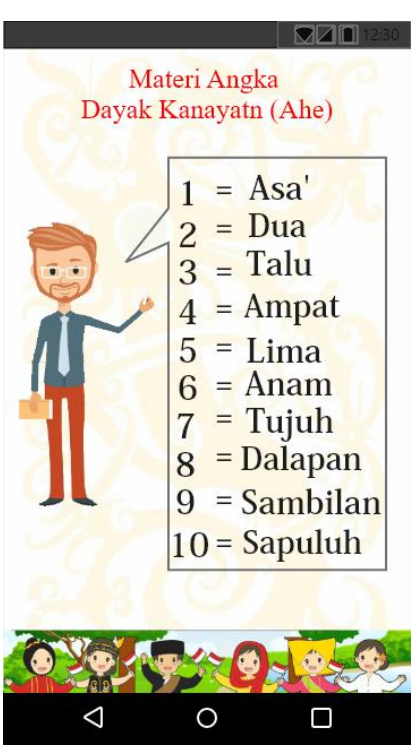

Fig. 5. Explanation Display

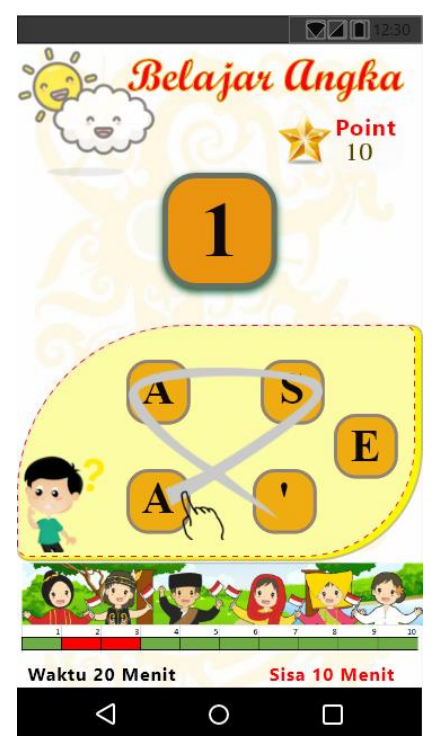

Fig. 6. Question Display 
The image quiz is in the form of letters. Fig 7 material is explained first by the avatar and then followed by a quiz. Example question shown in fig 8 is randomized letters, then arranged using drag and drop, so that it becomes the correct word. An example in fig 8 is a $\operatorname{dog}\left(A s u^{\prime}\right)$.

\subsection{Guess the image quiz interface}

In this quiz, the learning uses multiple choices. More questions are given in the form of local wisdom. In Fig 9, the material is explained first by an avatar; for example, the material is briefly explained about the traditional Dayak musical instrument, namely Sape. Example question in fig 10 is the picture next to is (Gambar ka'sampingk adalah).
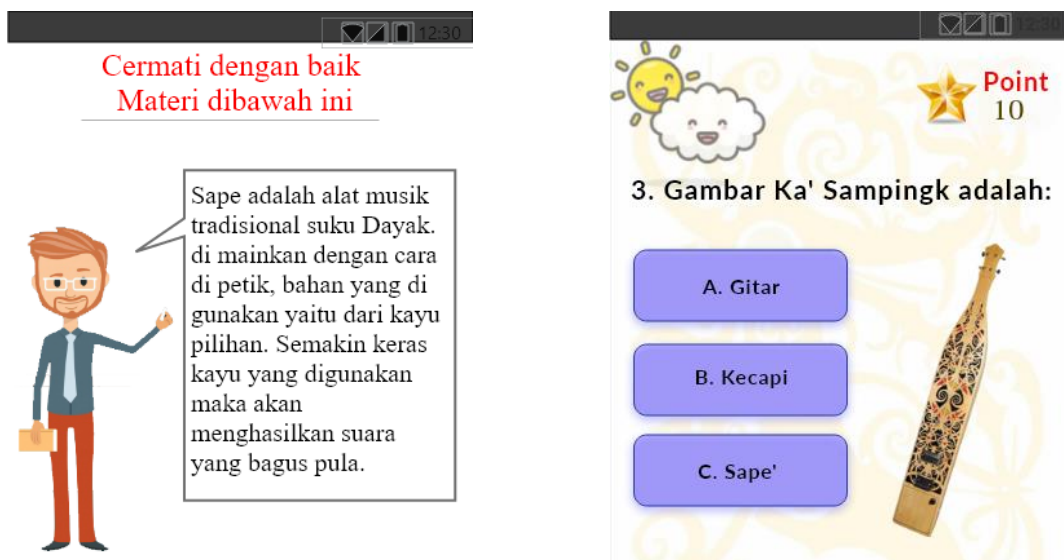

3. Gambar Ka' Sampingk adalah:
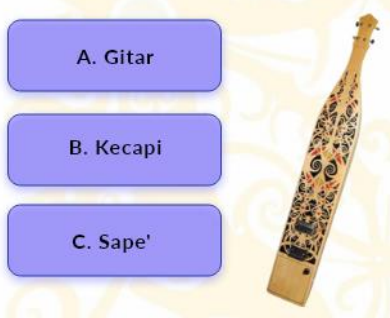

$\triangleleft$ ○

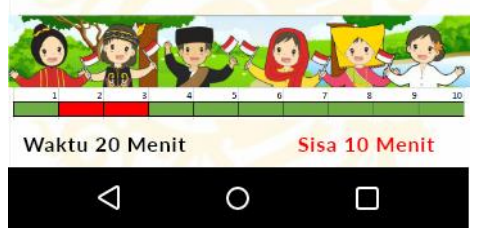

Fig. 7. Explanation Display

Fig. 8. Quiz Display

\subsection{Sentence quiz interface}

In this quiz, the answers use multiple choice. The question given is the question word form. In Fig 11 below, the material is explained by an avatar about the types of question words form. Example question in Fig 12 below is "what is your name?" (Sae damanyu?). 


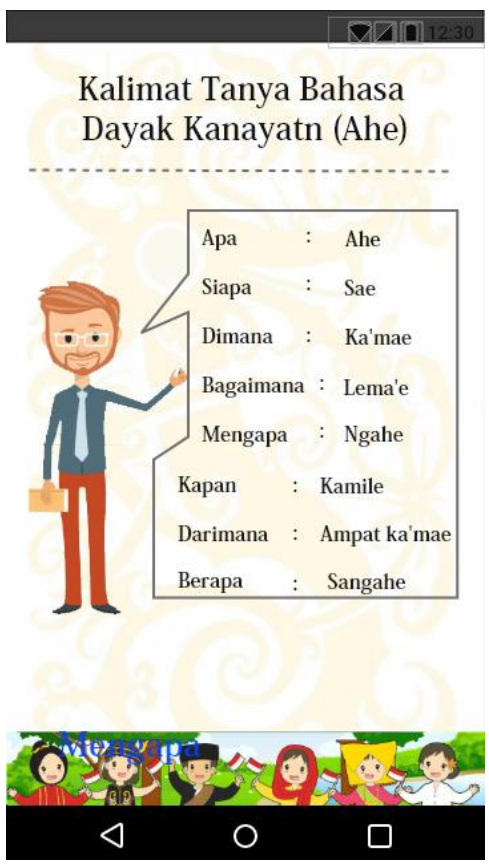

Fig. 9. Explanation Display

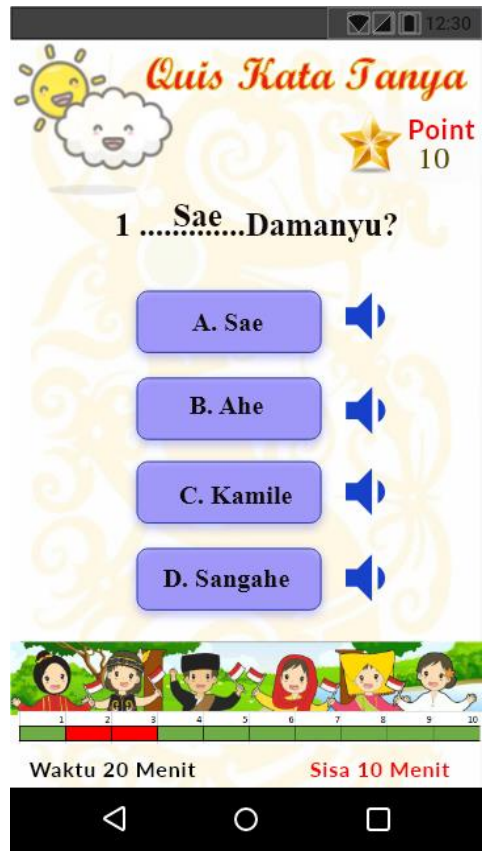

Fig. 10.Quiz Display

In fig 13 material and fig 14 below, the question is guessing the type of sentences. The types of sentences are interrogative sentences, declarative sentences, command sentences, and exclamation sentences. The example of a question is an interrogative sentence: What is your name? (Sae damanyu?). 


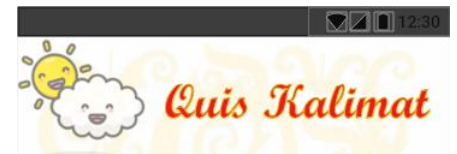

Berdasarkan isi atau fungsinya kalimat di bedakan menjadi 4 :
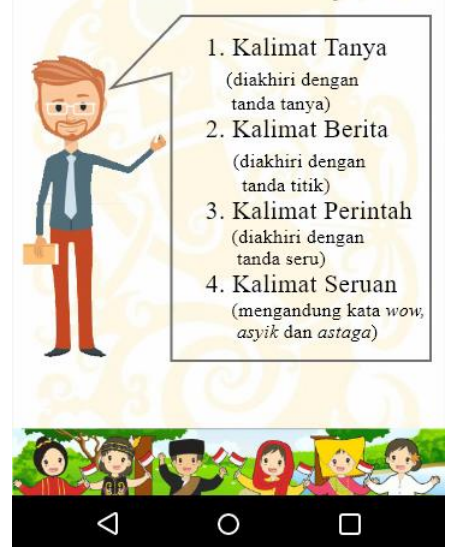

Fig. 11.Explanation Display

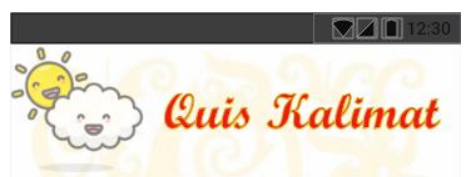

Berdasarkan isi atau fungsinya kalimat di bedakan menjadi 4:
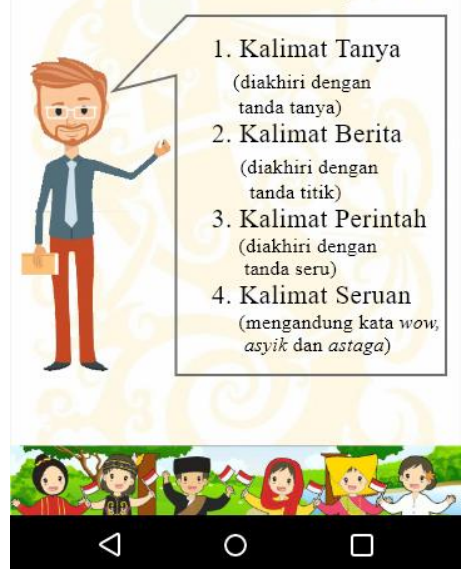

Fig. 13.Explanation Display

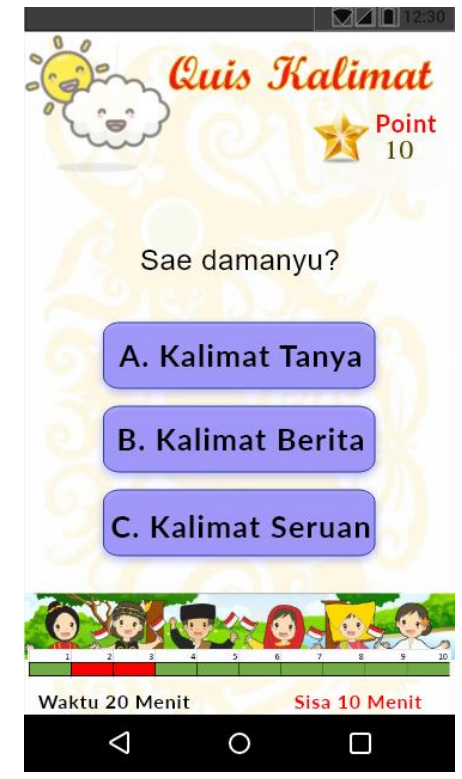

Fig. 12. Quiz Display

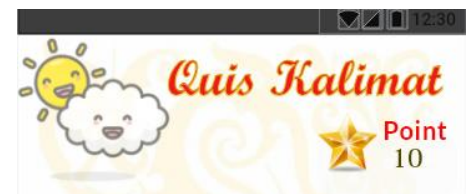

Sae damanyu?

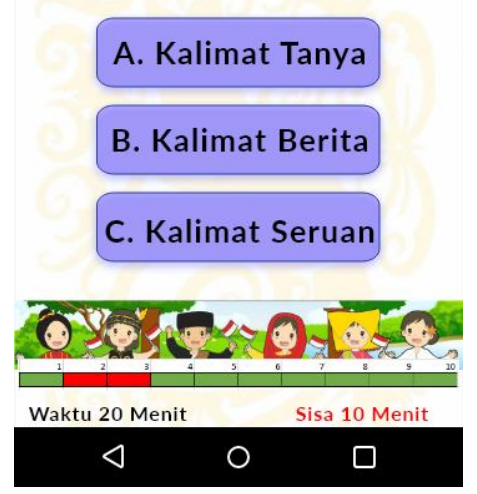

Fig. 14. Quiz Display 


\subsection{Words arrangement interface quiz}

In this quiz, the learning uses drag and drop. Fig 15 shows that the words are arranged in bold letters. The questions given are simple sentences that are often used in daily life by children. The example of a question in fig 16 is Ears for hearing (Tarenyenkng untok nangaratn).
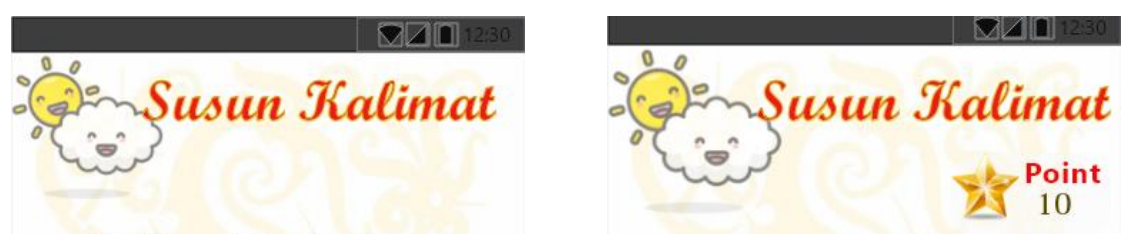

\section{Kalimat Sederhana}
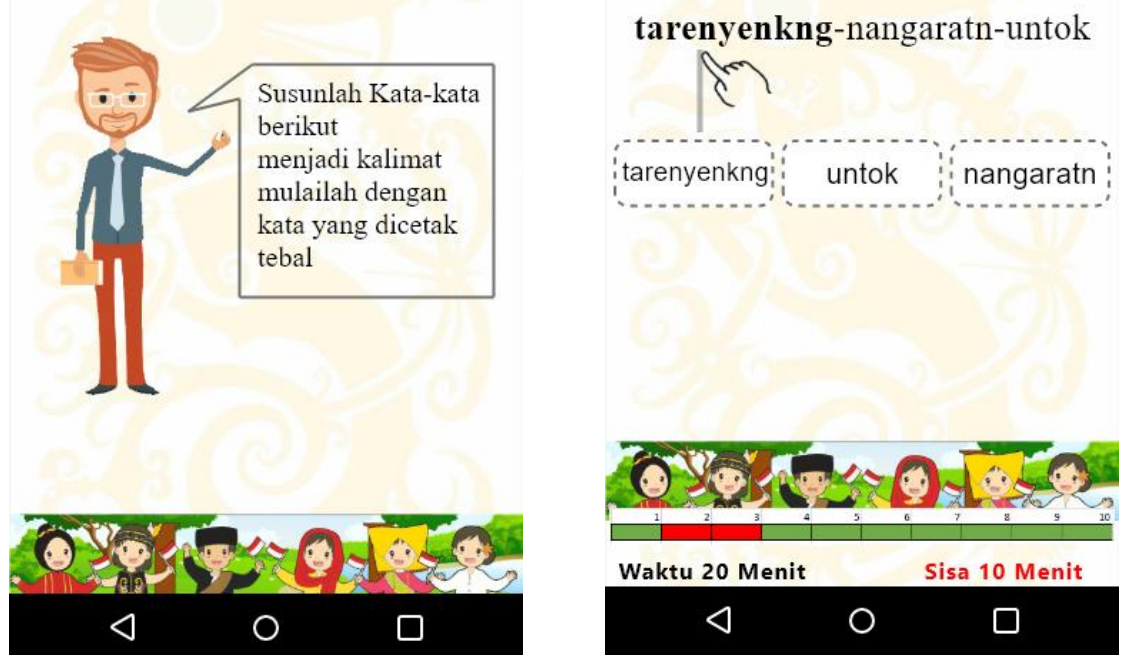

Fig. 15.Explanation Display

Fig. 16. Quiz Display

\subsection{Reward and point}

Rewards are given because they are considered capable of motivating children to learn. Giving rewards is in accordance with the points obtained in the game [28]. For one correct question, the player will get 10 points. From the verbal observation of communication from 20 children, the reward was in the form of a voucher, which could be redeemed in the form of school supplies. The results of verbal communication observations are shown in table 2. 
Table 2. Observed Reward

\begin{tabular}{|l|c|}
\hline \multicolumn{1}{|c|}{ Question } & Respondent \\
\hline If the prize is a shopping voucher for school supplies & 10 \\
\hline If the prize is a snack & 6 \\
\hline If the prize is a toy & 4 \\
\hline SUM & $\mathbf{2 0}$ \\
\hline
\end{tabular}

In the display, the reward is in the form of a shopping voucher for school supplies with a value corresponding to the point obtained. Vouchers are only valid for three days; reward vouchers can be seen in Figure 17.

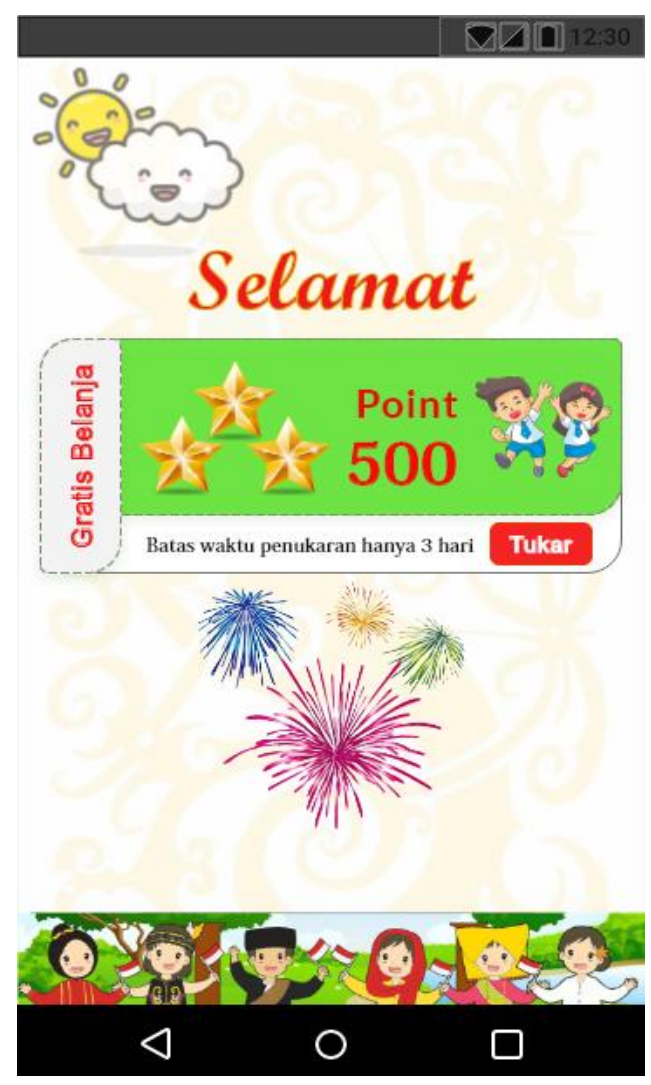

Fig. 17. Reward Display

Giving rewards is based on points earned. The reward obtained is based on the selection of the type of quiz. The number of points that can get a reward, as shown in Table 3 below: 
Table 3. Table Point and Reward

\begin{tabular}{|c|l|}
\hline Point & \multicolumn{1}{|c|}{ Reward } \\
\hline 100 & Pencil \\
\hline 200 & Pencil and eraser \\
\hline 300 & Book and Ruler \\
\hline 400 & Book, Ruler, Pencil and Eraser \\
\hline 500 & Pencil case, book, Ruler, pecsil and Eraser \\
\hline
\end{tabular}

The testing of Enggang Kanayatn Quiz was done using a design prototype installed in smartphones. After the games are finished, the children were asked to fill out a questionnaire on whether the design of this application could be accepted as a form of learning. The questionnaire consisted of 8 questions and 33 respondents. This questionnaire was adopted from the USE Questionnaire: Usefulness, Satisfaction, and Ease of use [29]. The form of questions can be seen in Table 4 below.

Table 4. Questionnaires

\begin{tabular}{|c|l|}
\hline No & \multicolumn{1}{|c|}{ Question } \\
\hline 1 & Learning Dayak Kanayatn (Ahe) using Mobile is useful for me \\
\hline 2 & Learning Dayak Kanayatn (Ahe) was according to my needs \\
\hline 3 & Kanayatn (Ahe) Dayak Language Learning Game is easy for me to use \\
\hline 4 & Kanayatn (Ahe) Regional Language Learning Game is easy for me to understand \\
\hline 5 & I learned Dayak Kanayatn (Ahe) using this method quickly \\
\hline 6 & I easily remember how to use this application \\
\hline 7 & Learning to use this cell phone is very fun for me \\
\hline 8 & This application design is very comfortable to use \\
\hline
\end{tabular}

Recapitulation of the testing of the EKQ test is shown in Fig. 18.

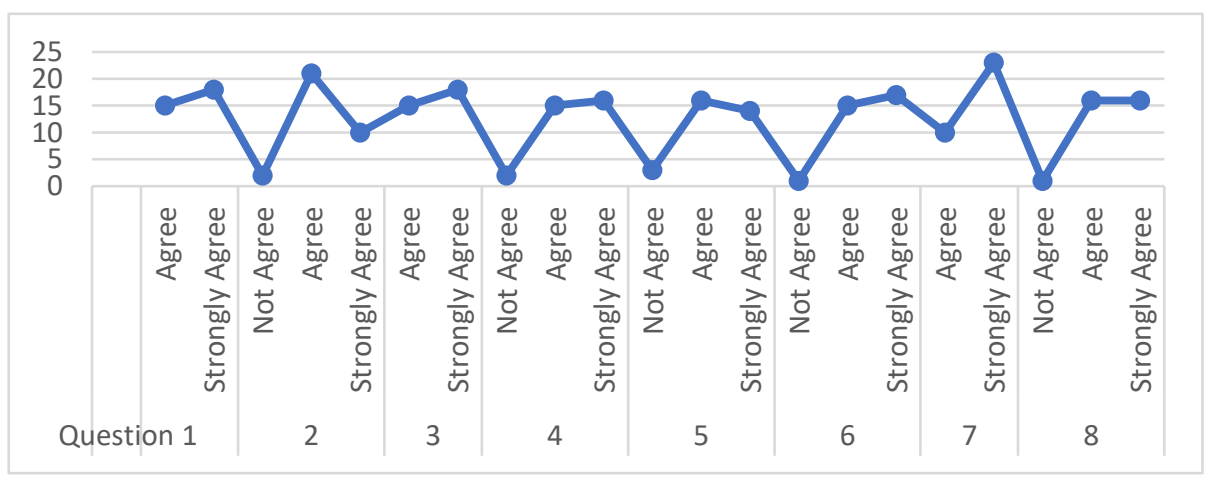

Fig. 18. Recapitulation Graph

From the results of testing of 33 children aged 9-10 years, the Enggang Kanayatn Quiz, by adopting the USE Questionnaire, can be concluded that the design of this mobile application is acceptable for children 


\section{Conclusion}

Learning regional languages using gamification based on the principle of pedagogy is more on the preservation of language and cultural wisdom, namely the case study of West Kalimantan, specifically the Dayak Kanayatn tribe with the Ahe language. Material explained by the avatar before the quiz will make it easier for children to understand answering questions. The form of the quiz displayed visually looks more attractive, so it makes children feel motivated. Guessing the picture quiz is more to local wisdom, for example, musical instruments, clothing, weapons typical of Dayak, and games typical of Dayak tribes. Points to be achieved with the reward that can be obtained will make children more motivated.

\section{References}

[1] K. P. B. D. DALAM and P. K. INDONESIA, DALAM, KEBIJAKAN PELINDUNGAN BAHASA DAERAH INDONESIA, PERUBAHAN KEBUDAYAAN. 2019.

[2] N. Xi and J. Hamari, "Does gamification satisfy needs? A study on the relationship between gamification features and intrinsic need satisfaction," Int. J. Inf. Manage., vol. 46, no. November 2018, pp. 210-221, 2019. https://doi.org/10.1016/j.ijinfomgt.2018.12.002

[3] N. Kristianti, N. Purnawati, and S. Suyoto, "Virtual Education with Puzzle Games for Early Childhood - A Study of Indonesia," Int. J. Eng. Pedagog., vol. 8, no. 2, p. 14, 2018. https://doi.org/10.3991/ijep.v8i2.7943

[4] S. Kadry and B. Ghazal, "Design and Assessment of Using Smartphone Application in the Classroom to Improve Students' Learning," Int. J. Eng. Pedagog., vol. 9, no. 2, p. 17, 2019. https://doi.org/10.3991/ijep.v9i2.9764

[5] R. S. Alsawaier, "The effect of gamification on motivation and engagement," Int. J. Inf. Learn. Technol., vol. 35, no. 1, pp. 56-79, 2018. https://doi.org/10.1108/IJILT-02-2017$\underline{0009}$

[6] A. Pritchard, Ways of Learning, Second Edi., vol. 246, no. 6365. London and New York, 1945. https://doi.org/10.1016/S0140-6736(45)91319-5

[7] H. Bicen and S. Kocakoyun, "Perceptions of students for gamification approach: Kahoot as a case study," Int. J. Emerg. Technol. Learn., vol. 13, no. 2, pp. 72-93, 2018. https://doi.org/10.3991/ijet.v13i02.7467

[8] Y. Luo and R. Baillargeon, "Do 12.5-month-old infants consider what objects others can see when interpreting their actions?," Cognition, vol. 105, no. 3, pp. 489-512, 2007. https://doi.org/10.1016/j.cognition.2006.10.007

[9] T. Nousiainen, M. Kangas, J. Rikala, and M. Vesisenaho, "Teacher competencies in gamebased pedagogy," Teach. Teach. Educ., vol. 74, pp. 85-97, 2018. https://doi.org/10.1016/j.tate.2018.04.012

[10] T. Carlotto and P. A. Jaques, "The effects of animated pedagogical agents in an English-asa-foreign-language learning environment," Int. J. Hum. Comput. Stud., vol. 95, pp. 15-26, 2016. https://doi.org/10.1016/j.ijhcs.2016.06.001

[11] Y. Colliver and N. Veraksa, "The aim of the game: A pedagogical tool to support young children's learning through play," Learn. Cult. Soc. Interact., vol. 21, no. April, pp. 296-310, 2019. https://doi.org/10.1016/j.lcsi.2019.03.001 
[12] J. Knijnik, R. Spaaij, and R. Jeanes, "Reading and writing the game: Creative and dialogic pedagogies in sports education," Think. Ski. Creat., vol. 32, pp. 42-50, 2019. https://doi.org/10.1016/j.tsc.2019.03.005

[13] A. Drigas and M. Karyotaki, "Learning Tools and Applications for Cognitive Improvement," Int. J. Eng. Pedagog., vol. 4, no. 3, p. 71, 2014. https://doi.org/10.3991/ijep.v4i3.3665

[14] P. Subsuku and K. Dayak, "Peta Sub Suku dan Bahasa Dayak," Institut Dayakologi. pp. 13, 2019.

[15] E. L. Bennett, A. J. Nyaoi, and J. Sompud, "Hornbills Buceros spp. And culture in northern Borneo: Can they continue to co-exist?," Biol. Conserv., vol. 82, no. 1, pp. 41-46, 1997. https://doi.org/10.1016/S0006-3207(97)00012-8

[16] K. Rosyidi, D. S. Kudori, and A. A. Supianto, "Design and Development Educational Media Diction of Madurese Language Level," 3rd Int. Conf. Sustain. Inf. Eng. Technol. SIET 2018 -Proc., pp. 180-185, 2019. https://doi.org/10.1109/SIET.2018.8693185

[17] A. A. Syahidi, A. A. Supianto, and H. Tolle, "Design and implementation of Bekantan Educational Game (BEG) as a Banjar language learning media," Int. J. Interact. Mob. Technol., vol. 13, no. 3, pp. 108-124, 2019. https://doi.org/10.3991/ijim.v12i7.9257

[18] N. S. Yahaya and S. N. A. Salam, "Mobile Learning Application for Children: Belajar Bersama Dino," Procedia - Soc. Behav. Sci., vol. 155, no. October, pp. 398-404, 2014. https://doi.org/10.1016/j.sbspro.2014.10.312

[19] T. Cash and C. Idea, "A Study on the Construction of a Culture Pedagogical Network Learning Space," iJET - Vol. 14, No. 17, 2019, vol. 14, no. 17, pp. 73-85, 2019. https://doi.org/10.3991/ijet.v14i17.11235

[20] G. P. Kusuma, E. K. Wigati, Y. Utomo, and L. K. Putera Suryapranata, "Analysis of Gamification Models in Education Using MDA Framework," Procedia Comput. Sci., vol. 135, pp. 385-392, 2018. https://doi.org/10.1016/j.procs.2018.08.187

[21] I. M. Ružic and M. Dumancic, "Gamification in education," Informatologia, vol. 48, no. 34, pp. 198-204, 2015.

[22] Z. Turan, Z. Avinc, K. Kara, and Y. Goktas, "Gamification and education: Achievements, cognitive loads, and views of students," Int. J. Emerg. Technol. Learn., vol. 11, no. 7, pp. 64-69, 2016. https://doi.org/10.3991/ijet.v11i07.5455

[23] M. H. Kurniawan, Suharjito, Diana, and G. Witjaksono, "Human Anatomy Learning Systems Using Augmented Reality on Mobile Application," Procedia Comput. Sci., vol. 135, pp. 80-88, 2018. https://doi.org/10.1016/j.procs.2018.08.152

[24] N. Kidi, B. Kanigoro, A. G. Salman, Y. L. Prasetio, I. Lokaadinugroho, and A. A. Sukmandhani, "Android Based Indonesian Information Culture Education Game," Procedia Comput. Sci., vol. 116, pp. 99-106, 2017. https://doi.org/10.1016/j.procs.2017.10.015

[25] J. Hamari and J. Koivisto, "Why do people use gamification services?," Int. J. Inf. Manage., vol. 35, no. 4, pp. 419-431, 2015. https://doi.org/10.1016/j.ijinfomgt.2015.04.006

[26] P. Zhang and X. Sui, "Application of digital music technology in music pedagogy," Int. J. Emerg. Technol. Learn., vol. 12, no. 12, pp. 1-13, 2017. https://doi.org/10.3991 lijet.v12i12.7966

[27] N. Pakprod, "Development of an Edutainment Instructional Model Using Learning Object for Electronic Book on Tablet Computer to Develop Emotional Quotient," Int. J. e-Education, e-Business, e-Management e-Learning, vol. 3, no. 2, pp. 3-6, 2013. https://doi.org/10.7763/IJEEEE.2013.V3.207

[28] P. A. Howard-Jones and T. Jay, "Reward, learning and games," Curr. Opin. Behav. Sci., vol. 10, pp. 65-72, 2016. https://doi.org/10.1016/j.cobeha.2016.04.015

[29] M. Gao, P. Kortum, and F. Oswald, "Psychometric Evaluation of the USE (Usefulness, Satisfaction, and Ease of use) Questionnaire for Reliability and Validity," Proc. Hum. Factors 
Ergon. Soc. Annu. Meet., vol. 62, no. 1, pp. 1414-1418, 2018 https://doi.org/10.1177/ $\underline{1541931218621322}$

\section{Authors}

Paulus Suryanto is a student at Magister Informatika, Universitas Atma Jaya Yogyakarta, Indonesia. Majoring in computer systems and data communication. He received his Bachelor Degree at STMIK AKAKOM Yogyakarta. His research interests are mobile applications and user interface design. Email: paulussuryanto8@gmail.com

Andi W.R. Emanuel graduated as BSEE from Purdue University USA in 1996, MSSE from The University of Melbourne Australia in 2001, and Doctor (Computer Science) from Gadjah Mada University Indonesia in 2012. He is a full-time lecturer at Magister Informatika, Universitas Atma Jaya Yogyakarta. His research Interest in Open Source Technology, Software Metrics, Software Quality, and Knowledge Discovery. Email: andi.emanuel@uajy.ac.id

Pranowo received the B.E degree in Mechanical Engineering from Universitas Gadjah Mada, Indonesia, in 1996, the M.Eng. degree in electrical engineering from the Universitas Gadjah Mada, Indonesia, in 2002. He obtained the Ph.D. degree in electrical engineering and information technology from the Universitas Gadjah Mada, Indonesia, in the year 2010. He is currently a full-time lecturer at Magister Informatika, Universitas Atma Jaya Yogyakarta, Indonesia. His research interests include numerical simulation and modeling, computer vision, and GPU parallel programming. Email: pranowo@uajy.ac.id

Article submitted 2019-12-26. Resubmitted 2020-02-05. Final acceptance 2020-02-05. Final version published as submitted by the authors. 